\title{
Contract modeling of investment projects in the field of oil and gas construction
}

\author{
A.S. Altemirova, ${ }^{1}$, I.V. Burenina ${ }^{2}$ \\ ${ }^{1}$ Ufa school of excellence, Ufa State Petroleum Technological University, Ufa, Russia \\ ${ }^{2}$ Ufa school of excellence, Ufa State Petroleum Technological University, Ufa, Russia
}

\begin{abstract}
. the purpose of this article is to select and justify the optimal contract model for one of the largest investment and construction projects of PJSC based on a preliminary assessment of the project under several alternative contracts. To achieve this goal, the following results were obtained: first, a classification of contracts for investment and construction projects (ICP) was developed, adapted to the specifics of the oil and gas business, second, the process steps for planning the contract model of oil and gas construction projects were formed, and third, a conclusion was made about the feasibility of using a particular contract model in terms of the project economy, its timing, the quality of decisions at each stage, and the risk management system.
\end{abstract}

\section{Introduction}

The research problem is reduced to determining whether there is a relationship between the contract strategy and the project indicators and, if so, how it affects the timing of its implementation, the quality of design decisions and the effectiveness of the risk management system.

To begin with, contract models in the Russian oil and gas industry evolved from the classical model («Traditional Design-Bid-Build»), according to which the customer independently carried out the main design work and involved contractors only at the construction stage, to progressive EPC(M)-models involving the delegation of authority to general contractors and the transfer of responsibility and risks to them [1].

A standard EPC-contract is understood to mean a construction contract, usually a «turnkey» with a Lump Sum price, according to which the contractor is responsible for engineering (E), procurement (P), construction (C) and commissioning of the facility [2]. It is advisable to use it in projects for which at the contracting stage it is possible to prepare a hard price offer (indicating the amount of work, their cost and associated risks), when attracting a sufficient amount of borrowed financing, when the attention of the customer / investor is absorbed by other projects and does not have sufficient management resources to switch to a new construction project, or when proven technical solutions exist on the market. A number of 
features of the EPC-model, in particular, the unwillingness of the customer to delegate responsibility in the field of subcontractor selection, the impossibility of valuing the project before concluding the contract itself, the need for a single payment by the customer of the entire contract amount led to the appearance of a complicated EPCM-contract [3]. An EPCMcontract(E-Engineering, P-Procurement, CM-Construction Management) is a general contract according to which the price is determined on the basis of the «Open Book» or cost-recovery method (Cost + Fee)[4].

In Russian and foreign practice, a standard EPC-contract («turnkey») is often identified with a General construction contract, which is not entirely true. Their key difference is that when using a turnkey contract, the contractor bears a single end-to-end technological, financial and legal responsibility for all project stages - «Engineering», «Procurement», «Construction», «Commissioning», «Site-services» (usually within 1 year, in the case of a prolonged contract), that is, is responsible for all project risks. In the case of using a General construction contract, the project risks are distributed between the customer and the contractor. For example, at the «Engineering» stage, the customer is engaged in conceptual design, the contractor develops working documentation / FEED-documentation; at the «Procurement» stage, the customer is responsible for the supply of main equipment, and the contractor is responsible for the supply of auxiliary equipment. Thus, the difference between these contracts is the level of integration of the contractor in the project work, the amount of risks that lie on it, and the mechanism for coordinating the results of each stage of the project.

According to one of the reputable analytical agencies, the share of EPC-contracts in the structure of the Russian oil and gas market will show a growth trend and will increase to $75 \%$ by 2030. The main factors contributing to such a leap will be: shorter deadlines for commissioning construction projects, the end-to-end technological responsibility of the EPCcontractor and the transfer of all customer risks to it, effective adaptation of technologies, including technologies of foreign licensors, and the profitability of such projects (high return on investment and early payback).

For effective modeling of contractual relations within the framework of the implementation of investment construction projects (ICP), it is necessary to have a clear understanding of the classification of contracts as such [5]. The existing classification takes into account several aspects at once: the procedure for selecting performers (competitive negotiations / tender procedures), the scope of competencies of the contractor (monocompetent / complex contracts) and the pricing method (price announcement / cost compensation / mixed pricing / application of the «Open Book» concept) [6]. An analysis of more than 70 oil and gas construction projects in Russian and foreign practice showed that not all of the contractual models of ICP are adapted to the specifics of the oil and gas business. Therefore, as part of the study, a new classification was developed based on two key parameters. Firstly, this is the amount of responsibility for the performance of work (Fig. 1). 


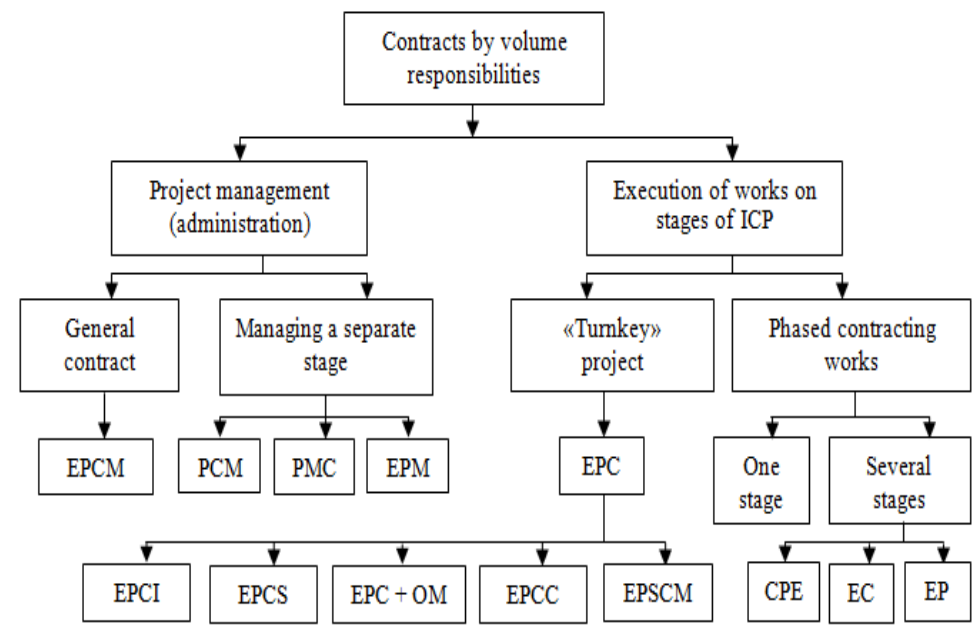

Fig. 1. Contract models of oil and gas construction projects by volume responsibilities (compiled by the authors).

The novelty of the developed classification is that all the presented contracts are systematized taking into account the degree of integration of the contractor in the design work. The most integrated contract model is EPC + OM (EPC + operation and maintenance), the least integrated option is construction management with a PMC-consultant [7]. As can be seen from figure 1, when choosing a contract model, the fundamental point is to understand the nature of the design work - either the customer gives the stages of ICP to management, then the choice in favor of the EPCM-contract «general contract» becomes obvious, or the contractor will perform specific work stages (in this case the conclusion of a EPC-contract «turnkey» and its derivatives is the most reliable and convenient solution). Since the concepts of «turnkey» and "general contract» are often synonymous in Russian practice [8], this automatically equates the EPC and EPCM-contracts, but technically this is absolutely not true, which is confirmed by the construction implementation schemes for such models, therefore, in figure 1 , they were spaced.

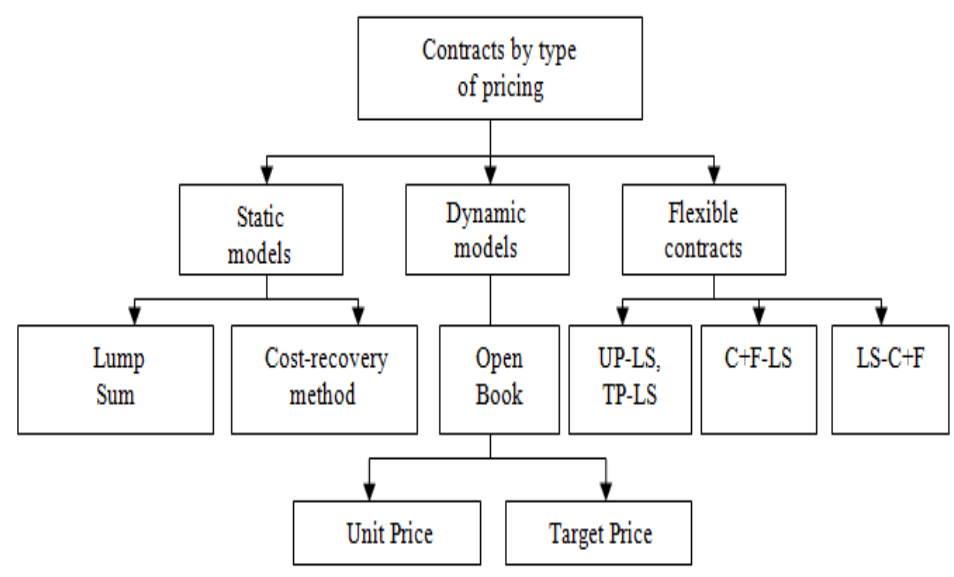

Fig. 2. Contract models of oil and gas construction projects by type of pricing(compiled by the authors). 
The second basis of the new classification was the type of pricing (Fig. 2). It is advisable to divide all models of contract pricing into static models, dynamic models that take into account changes in the cost of materials and cost indexation and convertible (flexible) contracts that imply a change in the method of determining the cost of a contract by the end of a project or a certain stage [9].

The strategic trend of Russian oil companies is the implementation of projects under a fixed price contract. Despite the high financial burden of the customer, the Lump Sum price involves the transfer of all risks from the customer to the work contractor, which increases the attractiveness of such a contractual model for the investor. The priority area for the practical application of the Lump Sum price is the EPC-contract («turnkey»), its derivative EPM, EPCM-2 (construction) [10]. The polar option of Lump Sum is the cost-recovery method (Cost + Fee), which, on the contrary, is the most risky for the customer and the least risky for the contractor. It is recommended for use if it is not possible to formulate a clear price offer at the stage of concluding the contract, so it is easy to adapt it in reconstruction, modernization, expansion and technological re-equipment projects [11].

Thus, the developed classification gives a clear understanding of how the volume and content of work affect the determination of their value and how the contractual model delimits risks between the customer and the contractor. In turn, the choice of the optimal pricing model and the competent distribution of the volume of work between the executors at each stage of the ICP can minimize the risks of disruption to the project deadlines, lower quality of design decisions, excess costs and failure to achieve design indicators declared at the project initiation stage [12].

At the moment, a single approach to the planning process and the formation of a contract model for oil and gas construction projects does not exist. Therefore, in the framework of the study, the author made an attempt to develop such a process, the graphic image of which is shown in figure 3. It can be seen that no matter what strategy the customer adheres to (presence of competencies / need to increase competencies/complete lack of competencies) the use of a complex contract, according to which the contractor three or more functions is the optimal solution because it provides a high degree of integration of the project team.

Combining the bases of the previously developed classification and the key elements of the contract, the author obtained four process steps for planning the contract model. Firstly, taking into account the level of customer competencies and their dynamics at each stage of the ICP based on a preliminary analysis of its behavior strategy. Secondly, accounting for the nature of the work (transfer by the customer of the volume of work for management or actual execution).Thirdly, selection of pricing models (either fixed-price targeting or the use of the «Open Book» concept with contract conversion).Fourthly, iterative optimization aimed at adjusting the contract taking into account earlier decisions regarding the volume of work, their cost and timing.

So, if the customer / investor of the project intends to relieve himself of responsibility for the work in full or in part and transfer the risks to the contractor, it is recommended to conclude a standard EPC-contract with a fixed price for the entire scope of work or to implement the project according to the truncated contract models for EP, EC-stages according to a similar pricing model (Fig. 3). If the contractor is hired to manage individual stages of the ICP, it is advisable to conclude an EPCM-contract, or hire specialists with managerial competencies (MC) (site-managers, PMC, CPE-consultants, etc.) and pay for their services according to the cost-recovery method (Cost + Fee), because in this case the physical volume of work is not fixed rigidly by the specifications of the project and can constantly change. In the case of applying non-standard contract models for Russian practice, for example, CMatR («Construction Management at Risk») [13], it is recommended to choose a separate pricing 
method for each phase of construction: for the pre-construction phase - Cost + Fee and Unit Price (for consultants), for the construction phase - Cost + Fee or Target Price.

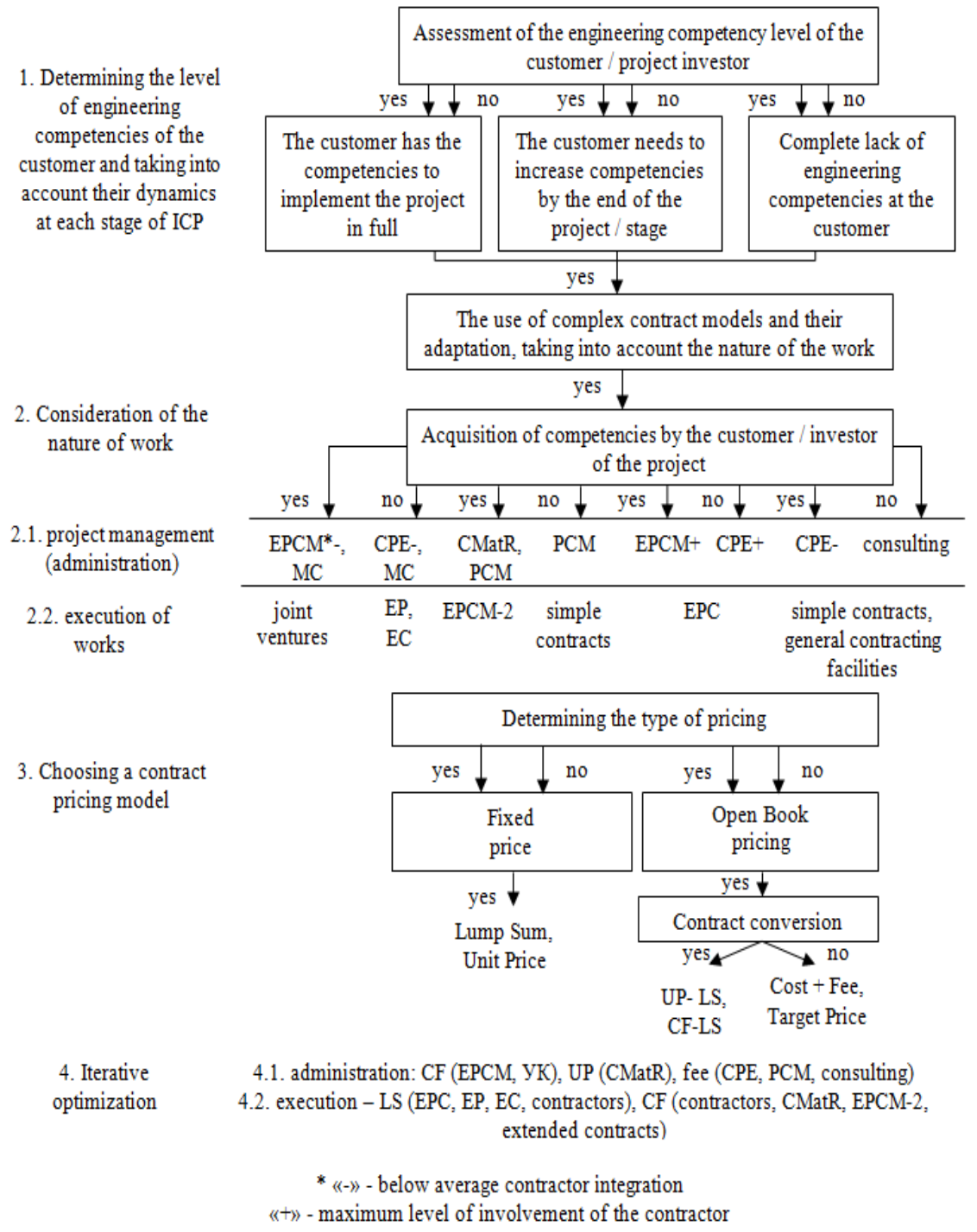

Fig. 3. Process steps for planning the contract model of oil and gas construction projects(compiled by the authors).

To assess the level of engineering competencies of the customer at the first process step of planning the contract model, the author of the article proposes classification of customers according to two aspects. Firstly, whether the construction object is profile for the customer or not. Secondly, further plans of the customer in relation to the facility under construction (the project operator will be the customer himself or a third party). Thus, we get four models of customers for investment projects in the oil and gas construction industry: active professional (AP), passive professional (PP), active non-professional (AN), passive non-professional (PN) (Table 1). 
Table 1. Types of customers of oil and gas investment construction projects(compiled by the authors).

\begin{tabular}{|c|c|c|c|}
\hline & \multicolumn{2}{|c|}{ Compliance with customer competencies } \\
\hline & & Profile object & Non-profile object \\
\hline \multirow{4}{*}{$\begin{array}{l}\text { Future } \\
\text { project } \\
\text { operator }\end{array}$} & & $\begin{array}{c}\text { ACTIVE PROFECCIONAL } \\
\text { («multi-lot», «Traditional Design- } \\
\text { Bid-Build») }\end{array}$ & $\begin{array}{c}\text { ACTIVE NON-PROFECCIONAL } \\
\text { («Traditional Design-Bid-Build», } \\
\text { general contract, EPS) }\end{array}$ \\
\hline & Customer & $\begin{array}{l}\text { The customer has a high level of } \\
\text { engineering competencies, } \\
\text { understands the technological or } \\
\text { production process, can } \\
\text { adequately assess the construction } \\
\text { costs. A large amount of work is } \\
\text { carried out by our own capital } \\
\text { construction service. }\end{array}$ & $\begin{array}{l}\text { The object is not included in the key } \\
\text { competencies of the customer, but it } \\
\text { is necessary for him to perform non- } \\
\text { core service functions. The customer } \\
\text { is forced to have such an object, has } \\
\text { managerial competencies and } \\
\text { requires careful consideration of } \\
\text { operating costs for the operation of } \\
\text { the object. }\end{array}$ \\
\hline & & $\begin{array}{l}\text { PASSIVE PROFECCIONAL } \\
\text { (general contract, partially EPC) }\end{array}$ & $\begin{array}{l}\text { PASSIVE NON-PROFECCIONAL } \\
\text { (EPC-model) }\end{array}$ \\
\hline & $\begin{array}{l}\text { Third } \\
\text { party }\end{array}$ & $\begin{array}{l}\text { A professional customer invests } \\
\text { in the construction of an object } \\
\text { for a related structure under the } \\
\text { supervision of the customer's } \\
\text { specialists or a real estate object } \\
\text { for the purpose of further resale, } \\
\text { sale in parts and for other } \\
\text { purposes. }\end{array}$ & $\begin{array}{l}\text { The customer is poorly aware of the } \\
\text { specifics of the design, construction } \\
\text { and operation of the facility, does not } \\
\text { intend to focus on this in the future. } \\
\text { The customer is an occasional or rare } \\
\text { moderator of ICP, professionally } \\
\text { insolvent. }\end{array}$ \\
\hline
\end{tabular}

The strategic trend of professional customers is cost compensation (Cost + Fee, Target Price), non-professional customers - price announcement (Lump Sum, Unit Price). However, depending on the specifics of a particular project, the customer can build a strategy of behavior according to the models of other types of customers: either take a passive position, abandoning the responsibility and risks of the project, despite the presence of high competencies, or take a non-professional position without competencies in certain stages of the project.

Table 2.The matrix of competencies of the customer and contractor at each stage of the ICP(compiled by the authors).

\begin{tabular}{|c|c|c|c|c|c|c|c|c|}
\hline \multirow{2}{*}{ Project stage } & \multicolumn{2}{|c|}{$\begin{array}{c}\text { Active } \\
\text { professional }\end{array}$} & \multicolumn{2}{|c|}{$\begin{array}{l}\text { Active non- } \\
\text { professional }\end{array}$} & \multicolumn{2}{|c|}{ Passive professional } & \multicolumn{2}{|c|}{$\begin{array}{l}\text { Passive non- } \\
\text { professional }\end{array}$} \\
\hline & $\begin{array}{c}\text { Custome } \\
\mathrm{r}\end{array}$ & $\begin{array}{c}\text { Contract } \\
\text { or }\end{array}$ & $\begin{array}{c}\text { Custome } \\
\mathrm{r}\end{array}$ & $\begin{array}{c}\text { Contract } \\
\text { or }\end{array}$ & $\begin{array}{c}\text { Custome } \\
\mathrm{r}\end{array}$ & $\begin{array}{c}\text { Contract } \\
\text { or }\end{array}$ & $\begin{array}{c}\text { Custome } \\
\mathrm{r}\end{array}$ & $\begin{array}{c}\text { Contract } \\
\text { or }\end{array}$ \\
\hline $\begin{array}{l}\text { Investment } \\
\text { planning }\end{array}$ & + & & + & + & + & & + & + \\
\hline Financing & + & & + & & + & & + & + \\
\hline $\begin{array}{l}\text { Business- } \\
\text { planning }\end{array}$ & + & & + & + & + & & + & + \\
\hline $\begin{array}{c}\text { Project } \\
\text { management }\end{array}$ & + & & + & + & + & + & + & + \\
\hline Engineering & + & + & + & + & + & + & & + \\
\hline Procurement & + & + & + & + & & + & & + \\
\hline Construction & & + & + & + & & + & & + \\
\hline
\end{tabular}




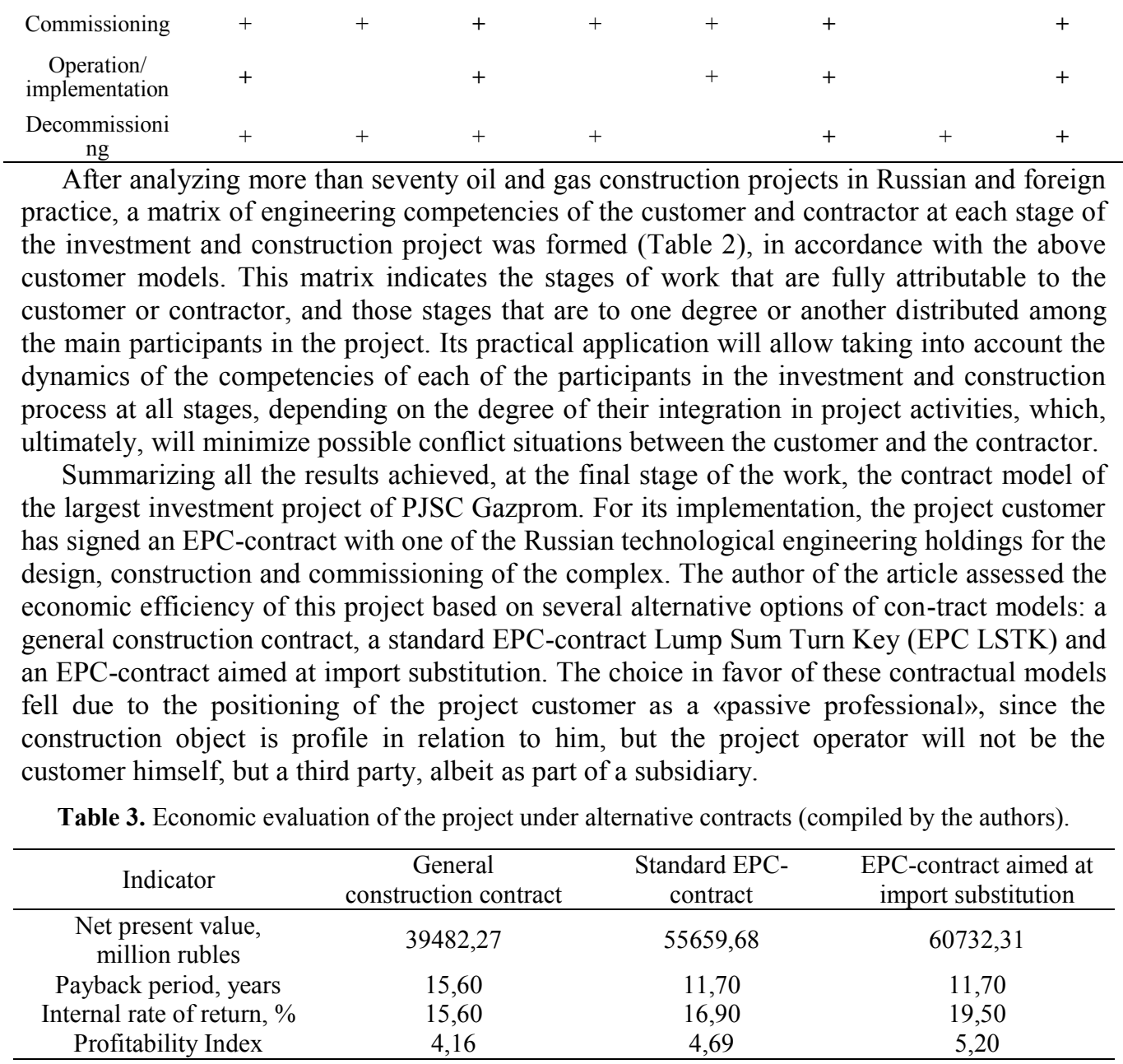

The results of the economic assessment showed that the EPC-model is optimal for this project (Table 6). The use of a standard EPC-contract allows to reduce the construction stage by 2 times, compared with the implementation of the project under a general construction contract, due to several factors. Firstly, using a contract supply chain, according to which all processes at the «Procurement» stage are administered only by the contractor, and the customer receives equipment, structures and materials in the form of a ready-made «turnkey» object, without spending time on negotiations with suppliers, equipment acceptance, forwarding and so on. Secondly, implementation of parallel design, when parallel to the preparation of working and design documentation, the equipment was contracted for a long production cycle and part of the construction work.

The net present value of the project under the EPC-contract is $41 \%$ higher than under the simple general contract, the project pays off 3 years earlier and the return on investment is high-er. Speaking about the quality of design solutions, the high level of professional competencies of the EPC-contractor and its easier access to the technology of the foreign licensor leads to an increase in the quality of work on the entire EPC-chain. The project risk management system becomes more efficient by transferring all risks from the customer to the 
contractor (the «one window» principle), which bears end-to-end technological, financial and legal responsibility.

However, a greater economic effect in the project under consideration is ensured by the use of an EPC-contract aimed at import substitution. For its application it is necessary to have the potential for import substitution at all stages of the ICP, which was not possible at the time of the initiation and implementation of the project. Therefore, this contract model can be considered as a target for similar projects in the future.

Summarizing the above, it becomes obvious that, indeed, the contract model has a significant impact on the project's economy, the timing of its implementation, the quality of design solutions and the effectiveness of the risk management system, which is confirmed by the results of the economic assessment of one of the investment and construction projects. The potential for increasing the efficiency and profitability of the project by reducing errors at the contracting stage can be at least $25-30 \%$, and the maximum value approaches the value of the contract itself. The classification of contracts developed as part of the study, adapted to the specifics of the oil and gas business, allows the customer and the project contractor to build an effective contractual strategy that takes into account the volume, nature of work and their corresponding pricing models. The proposed planning mechanism contributes to the development of an optimal set of stages of the investment and construction project, formed at the stage of a deep analytical approach. Of course, the highlighted steps of contract planning are not a panacea for solving problems in the field of contract modeling. From project to project, they can change, because, firstly, some projects have several life cycles, which increase the extremeness of the project and require adjustment of the process steps [14], and secondly, the customer's engineering competencies tend to increase. But the developed steps can be used as a fundamental basis, which is adjusted from time to time depending on the intentions of the parties to the contract, the specifics of the project and the impact of any external factors.

\section{References}

1. E.A. Kalinenko, Engineering services in investment projects of the Russian oil refining industry: tasks and opportunities for cooperation, Sphere Oil and Gas, 4, 62 (2018).

2. V.B. Lipavsky, Moscow: Ost Legal Law Firm, Structuring, conclusion and execution, (2015).

3. A.A. Laznik, V.Yu. Linnik, Identification of areas of best practice for managing EPC(M)projects based on world market analysis, Bulletin of the State University of Management, 6, 28 (2017).

4. V.B. Lipavsky, The main contractual forms for the implementation of construction investment projects EPC and EPCM, Oil, Gas, Law, 4, 53 (2009).

5. S.V. Bovteev, Management of investment and construction projects, (SPb: Publishing house of the Polytechnic University 2013).

6. V.I. Malakhov, Contract strategies for the implementation of investment and construction projects (basic course), (Moscow: DPK Press 2018).

7. A.A. Laznik, International market for EPC(M)-contracts, Reforms in Russia and Problems of Management, 2, 61 (2017).

8. A. Danilushkina, Turnkey: EPC contracts of Gazprom Neft, Siberian Oil, 100, 38 (2008).

9. D. Grishkovets, EPCM Market. Kommersant, Contractual Services. Business Guide, 187, 27 (2008). 
10. E.B. Smirnov, Typical forms of international construction contracts and their adaptation to the conditions of Russia, Transport business of Russia, 8, 61 (2011).

11. A.A. Laznik, Analysis of the development prospects of the EPC(M)-service market in the field of designing oil industry facilities, Reforms in Russia and Problems of Management, 2, 138 (2105)

12. A. Kozhushko, EPC Model Contract: Key Risks, Contract Law, 2, 29 (2014).

13. S.A. Mishin, EPC Code. Myths Secrets Practice (project book),(Moscow: Independent Consultant 2013).

14. R.B. Mikhailov, About some features of the contractual forms of innovative activity, Territory of Science, 4, 133 (2014). 